\section{Nasopharyngeal secretions as source of material for identification of respiratory viruses in infants and young children}

Sir,

We report the results of a preliminary virological study of nasopharyngeal secretions (NPS) in children under 2 years of age carried out between November 1973 and May 1974 at the South London Hospital in collaboration with the Department of Virology, Brompton Hospital. The purpose was primarily to establish the indirect technique of immunofluorescence (IF) for the diagnosis of myxovirus infections using NPS and to compare the efficiency of this method with that of isolation by cell culture. At the same time the isolation rate of all types of respiratory virus obtained from NPS by cell culture was compared with that from nasal and throat $(\mathrm{N} / \mathrm{T})$ swabs. The age distribution and clinical manifestations of respiratory viral infection in these children were examined.

NPS were aspirated within 7 days of onset of symptoms using standard disposable mucus extractors. 16 infants aged from 6-9 weeks with minor colds attending the well baby clinic, and 24 children aged 3 months to 2 years admitted to the ward with more serious illnesses were investigated. Specimens were inoculated into cell cultures within 4 hours. Sixteen out of 19 specimens from which myxoviruses were isolated on cell culture were examined by IF. The remaining 3 contained too few cells for this method. Viruses were identified in $\mathbf{1 5}$ of these specimens. The diagnosis of myxovirus infections was made within 24 hours by IF compared with 7-12 days by cell culture and neutralization tests. Myxoviruses isolated on cell cultures were also typed by IF, as soon as the cytopathic effect was observed. This latter method reduced the time normally taken for typing of isolates.

The isolation rate of all types of respiratory viruses was $60 \%$ from the 40 specimens of NPS inoculated into cell cultures compared with $35 \%$ from $\mathrm{N} / \mathrm{T}$ swabs obtained from children of the same age in a 5-year survey in general practice (Horn et al., 1975). NPS were therefore superior to $\mathrm{N} / \mathrm{T}$ as a source of material for virological studies in infants and young children.

The distribution of infection by respiratory viruses was examined according to age and category of illness (Table). Respiratory syncytial virus and parainfluenza 3 virus infections were found in infants aged 0-6 months who had been admitted to the ward suffering from bronchiolitis or pneumonia. These associations have already been shown using IF techniques (Gardner et al., 1971). These same agents, however, were associated with only minor respiratory illnesses in 6-9 week old infants attending the well baby clinic, and in the survey in general practice severe illness occurred in only 4 out of 14 infants infected by RS virus (Horn et al., 1975). Mild illnesses have also been reported in newborn infants during an outbreak of respiratory syncytial virus infection in a maternity ward (Neligan et al., 1970). This is of interest since it has already been shown that, in general, illness due to respiratory syncytial virus is more severe the younger the infant (Jacobs et al., 1971). The findings indicate that not only do age and viral pathogenicity determine severity of illness but also that other

\title{
TABLE
}

Viruses identified by cell culture of nasopharyngeal secretions

\begin{tabular}{|c|c|c|c|c|c|c|c|c|}
\hline $\begin{array}{l}\text { Children } \\
\text { investigated }\end{array}$ & $\begin{array}{l}\text { Category } \\
\text { respiratory } \\
\text { illness }\end{array}$ & Rhinoviruses & $\begin{array}{c}\text { Parainfluenza } \\
\text { virus } 3\end{array}$ & $\begin{array}{l}\text { Respiratory } \\
\text { syncytial } \\
\text { virus }\end{array}$ & $\underset{\mathbf{A}}{\text { Influenza }}$ & $\begin{array}{c}\text { Coxsackie } \\
\text { B2 }\end{array}$ & $\begin{array}{c}\text { Adenovirus } \\
\mathbf{2}\end{array}$ & $\begin{array}{c}\text { Total } \\
\text { investigations }\end{array}$ \\
\hline $\begin{array}{l}\text { Well baby } \\
\text { clinic } \\
\text { (aged 6-9 w) }\end{array}$ & Upper & 2 & 2 & 3 & - & 1 & - & 16 \\
\hline $\begin{array}{c}\text { Inpatients } \\
0-6 \mathrm{~m}\end{array}$ & $\begin{array}{l}\text { Upper } \\
\text { Bronchitis } \\
\text { Bronchiolitis } \\
\text { Pneumonia }\end{array}$ & $\begin{array}{l}1 \\
- \\
-\end{array}$ & $\begin{array}{l}1 \\
1 \\
1\end{array}$ & $\begin{array}{l}1 \\
3 \\
3 \\
-\end{array}$ & $\begin{array}{l}- \\
\overline{-} \\
-\end{array}$ & $\begin{array}{l}- \\
- \\
-\end{array}$ & $\begin{array}{l}\overline{-} \\
\overline{-}\end{array}$ & $\left.\begin{array}{l}3 \\
4 \\
4 \\
3\end{array}\right\} 14$ \\
\hline $7-24 \mathrm{~m}$ & $\begin{array}{l}\text { Upper } \\
\text { Bronchitis } \\
\text { Bronchiolitis } \\
\text { Pneumonia }\end{array}$ & $\begin{array}{l}- \\
- \\
-\end{array}$ & $\begin{array}{l}\overline{2} \\
- \\
-\end{array}$ & $\begin{array}{l}- \\
\overline{1}\end{array}$ & $\begin{array}{l}\overline{1} \\
\overline{1}\end{array}$ & $\begin{array}{l}- \\
- \\
-\end{array}$ & $\begin{array}{l}\overline{1} \\
\overline{-}\end{array}$ & $\left.\begin{array}{l}2 \\
4 \\
1 \\
3\end{array}\right\} 10$ \\
\hline
\end{tabular}



determining the clinical response to infection.

\section{MARY E. C. HORN, PAUL TAYLOR, and SUSAN J. YEALLAND \\ South London Hospital for Women and Children, Clapham Common, London SW4 and Department of Virology, Brompton Hospital, London SW3.}

\section{REFERENCES}

Gardner, P. S., McQuillin, J., McGuckin, R., and Ditchburn, R. K. (1971). Observations on clinical and immunofluorescent diagnosis of parainfluenza virus infections. British Medical Fournal, 2, 7 .

Horn, M. E. C., Brain, E., Gregg, I., Yealland, S. J., and Inglis, J. M. (1975). Respiratory viral infection in childhood. A survey in general practice. Roehampton, 1967-1972. fournal of Hygiene, 74, 157.

Jacobs, J. W., Peacock, D. B., Corner, B. D., Caul, E. O., and Clarke, S. K. R. (1971). Respiratory syncytial and other viruses associated with respiratory disease in infants. Lancet, $1,871$.

Neligan, G. A., Steiner, H., Gardner, P. S., and McQuillin, J. (1970). Respiratory syncytial virus infection in the newborn. British Medical fournal, 3, 146. factors, possibly immunological, must be involved in

\section{REFERENCES}

Buckler, J. M. H. (1972). Exercise as a screening test for growth hormone release. Acta Endocrinologica, 69, 219.

Wise, P. H., Burnet, R. B., Geary, T. D., and Berriman, H. (1975). Selective impairment of growth hormone response to physiological stimuli. Archives of Disease in Childhood, 50, 210.

Dr. Wise and colleagues comment as follows:

We agree entirely with the comments of Dr. Buckler. Since submission of our original paper, and in an attempt to provide a more consistently effective stimulus, we have modified our exercise test to a 10- to 20-minute period (depending on endurance) workload of 450 kilopond $(4410 \mathrm{~N}) \mathrm{m} / \mathrm{min}$ using a bicycle ergometer (Monark). Samples for growth hormone assay were taken at 1 and 15 minutes after completion of exercise, so that a minimum interval of 25 minutes from the start of exercise to final sampling applied to all cases. Over $90 \%$ of 24 subjects with short stature, and who were not growth-hormone deficient exceeded $14 \mu \mathrm{U} / \mathrm{ml}$ in one or both of these samples.

P. H. WISE, R. B. BURNET, R. D. GEARY, and H. BERRIMAN Endocrine Unit, Royal Adelaide Hospital, North Terrace, Adelaide, South Australia 5000

\section{Exercise as a physiological stimulus to growth hormone release}

Sir,

In comparing methods of stimulating growth hormone release, Wise et al. (1975) included exercise, but reported that levels exceeding $14 \mu \mathrm{U} / \mathrm{ml}$ were only obtained in $50 \%$ of cases who were not growth-hormone deficient. The technique they described involved blood sampling 10 minutes after completion of exercise to mild exhaustion by stair climbing. Extensive studies on several subjects (Buckler, 1972) have shown that plasma growth hormone levels associated with exercise do not begin to rise for 10-15 minutes and do not reach peak values until 25-30 minutes after the start of exercise. Unless the children in the report by Wise et al. climbed stairs for at least 15 minutes, it is unlikely that the greatest response in plasma growth hormone levels would be detected by their method. It is possible that others who report poor responses with this method of exercise testing may have failed to take the blood sample at the correct time, namely 25-30 minutes after the start of a short (5-10 minute) period of intensive exercise.

J. M. H. BUCKLER University of Leeds, Department of Paediatrics and Child Health, 27 Blundell Street, Leeds LS1 3ET

\section{Maternal histidinaemia}

Sir,

Recently two questions have been raised concerning the inherited biochemical trait histidinaemia. (1) Is the trait a benign metabolic disorder (Popkin et al., 1974; Levy, Shih, and Madigan, 1974)? (2) Are children born of histidinaemic mothers at risk of harm during gestation (Neville et al., 1971; Lyon, Gardner, and Veale, 1974)? The answers to these questions are important, since the unnecessary administration of a histidine-deficient diet to pregnant women or to young infants with biochemical histidinaemia might result in a harmful nutritional imbalance. We report a normal histidinaemic mother with 4 normal children.

Plasma and urine amino acids were measured with an amino acid analyser. Imidazolepyruvic acid was determined spectrophotometrically by the borate-arsenate method (Lin et al., 1958). Imidazolelactic acid, imidazoleacetic acid, and $\mathrm{N}$-acetylhistidine were estimated by visual comparison of colour produced by diazotized sulphanilic acid with materials in aliquots of urine and with known amounts of authentic compounds after two-dimensional paper chromatography on Whatman No. 3MM filter paper in pyridine-acetone-3 $N$ ammonium hydroxide $(50: 30: 25)$, followed by isopropyl alcohol-formic acid (88\%) -water (8:1:1).

The mother was on our staff; her plasma amino acids were measured during collection of data on plasma amino acid levels of normal children and adults. Biochemically she had typical histidinaemia. Her fasting plasma histidine levels were $0.73,0.52$, and 0.79 $\mu \mathrm{mol} / \mathrm{ml}$ in 3 samples collected over a 6 -month period. 